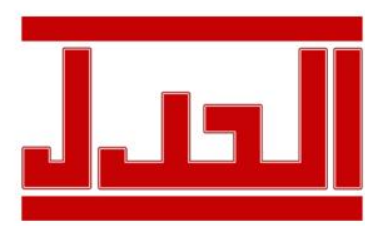

ISSN: $1979-4940$

E-ISSN: 2477-0124
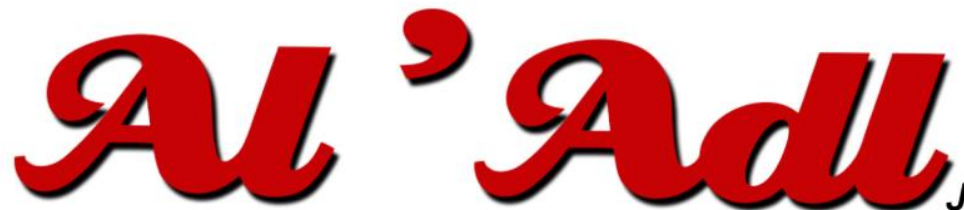

Jurnal Hukum

Editorial Office: Faculty of Law, Islamic University Of Kalimantan,

Jalan Adhyaksa No. 2 Kayutangi Banjarmasin, Kalimantan Selatan, Indonesia (70123)

Email: al_adl@uniska-bjm.ac.id

Web: http://ojs.uniska-bjm.ac.id

\title{
PENATAAN KEMBALI DESAIN KELEMBAGAAN KOMISI NASIONAL DISABILITAS SEBAGAI LEMBAGA INDEPENDEN DI INDONESIA
}

\author{
${ }^{[1]}$ Rayhan Naufaldi Hidayat* \& ${ }^{[2]}$ Andradito Muhammad Wisnu* \\ Fakultas Syariah dan Hukum Universitas Islam Negeri Syarif Hidayatullah Jakarta \\ Jl. Ir H. Juanda No.95, Kota Tangerang Selatan, Banten, 15412 \\ Email: ${ }^{[1]}$ rayhan.naufaldi18@mhs.uinjkt.ac.id \\ ${ }^{[2]}$ aandra.mw18@mhs.uinjkt.ac.id
}

$\begin{array}{ll}\text { Submitted } & : \text { 1 Juni } 2021 \\ \text { Revised } & : \text { 1 Juli 2021 } \\ \text { Accepted } & : \text { 17 Juli 2021 } \\ \text { Published } & : \text { 29 Juli 2021 }\end{array}$

(C) Licence by CC BY-NC-SA

\section{Abstract}

Indonesia is working hard to create a country that is friendly for people with disabilities. One of the concrete efforts that have been made is to form an independent agency that specifically handles the disability sector. The agency is in the form of a commission on behalf of the National Commission for Disabilities. Its formation is based on Presidential Regulation Number 68 of 2020 concerning the National Commission for Disabilities. In this regard, this study will examine further the institutional design of the commission from the point of view of state institutional law. The type of research used in this research is normative legal research with a statutory approach. The results of this study indicate that there are still serious legal problems related to the institutional design of the National Commission for Disabilities as an independent agency. This can be seen in Article 9 of Presidential Regulation Number 68 of 2020 concerning the National Commission for Disabilities which embeds the secretariat of the commission within the Ministry of Social Affairs, so that directly or indirectly the implementation and supervision functions of the National Commission for Disabilities are not optimal. The implication that arises from this condition is the rise of cases of violations of the rights of persons with disabilities. Therefore, it is necessary to restructure the institutional design of the National Commission for Disabilities as an independent agency so that it can carry out its duties, principals and functions optimally, so that Indonesia's efforts to create a disability-friendly country can actually be realized.

Keywords: Persons with Disabilities; National Commission for Disabilities; Independent Agency.

\section{Abstrak}

Indonesia tengah berupaya keras untuk mewujudkan negeri yang ramah bagi penyandang disabilitas. Salah satu upaya konkrit yang telah dilakukan yaitu membentuk lembaga independen yang khusus menangani sektor disabilitas. Lembaga tersebut berupa komisi atas nama Komisi Nasional Disabilitas. Pembentukannya didasarkan pada Peraturan Presiden Nomor 68 Tahun 2020 tentang Komisi Nasional Disabilitas. Berkenaan dengan hal itu, penelitian ini akan mengkaji lebih jauh terkait desain kelembagaan dari komisi tersebut dalam kaca mata hukum kelembagaan negara. Adapun jenis penelitian yang digunakan dalam penelitian ini ialah penelitian hukum normatif dengan pendekatan perundang-undangan. Hasil dari penelitian ini menunjukkan bahwa masih adanya 
problematika hukum yang cukup serius terkait desain kelembagaan dari Komisi Nasional Disabilitas sebagai lembaga independen. Hal itu tampak pada Pasal 9 Peraturan Presiden Nomor 68 Tahun 2020 tentang Komisi Nasional Disabilitas yang melekatkan kesekretariatan dari komisi tersebut dalam internal Kementerian di bidang sosial, sehingga secara langsung maupun tidak langsung membuat fungsi pelaksanaan dan pengawasan dari Komisi Nasional Disabilitas menjadi tidak optimal. Implikasi yang timbul dari kondisi tersebut ialah maraknya kasus-kasus pelanggaran terhadap hak-hak penyandang disabilitas. Oleh karena itu, diperlukannya upaya penataan kembali terhadap desain kelembagaan dari Komisi Nasional Disabilitas sebagai lembaga independen agar dapat menjalankan tugas, pokok dan fungsinya secara optimal, sehingga upaya Indonesia dalam menciptakan negeri yang ramah disabilitas dapat benar-benar terwujud.

Kata Kunci: Penyandang Disabilitas; Komisi Nasional Disabilitas; Lembaga Independen.

\section{PENDAHULUAN}

Keberadaan manusia sebagai salah satu makhluk hidup di atas muka bumi sangatlah istimewa. Penciptaannya oleh Tuhan Yang Maha Esa mengandung makna-makna universal yang sangat mendalam. ${ }^{1}$ Diferensiasi yang bersifat kodrati antar manusia yang satu dengan yang lainnya menjadi satu kesatuan sistem kehidupan untuk saling melengkapi satu sama lain. Manusia yang satu bisa jadi memiliki kelebihan secara fisik, namun menyimpan kelemahan pula dari segi non fisiknya. Begitu pula sebaliknya, manusia yang lain boleh saja mempunyai keterbatasan dari segi fisik, akan tetapi dalam dirinya pasti tersimpan kemampuankemampuan khusus yang tidak dimiliki oleh manusia selain dirinya. ${ }^{2}$

Sekelompok manusia yang dianugerahkan suatu keterbatasan khusus dalam dirinya baik itu secara fisik ataupun non fisik kerap kali diberi label oleh masyarakat umum sebagai penyandang disabilitas. ${ }^{3}$ Seluruh keterbatasan yang menyatu dalam dirinya tentu tidak serta merta menghalangi penyandang disabilitas sebagai subjek dari hak asasi manusia. Hal itu ditekankan pula oleh Theresia Degener yang mengatakan bahwa "Human rights are fundamental rights. They do not require a certain health status or a condition of functioning." 4 Seperangkat hak fundamental tersebut sifatnya sangatlah krusial, karena penyandang disabilitas tanpanya tidak dapat hidup layaknya manusia. ${ }^{5}$

Pentingnya himpunan hak yang bersifat asasi bagi penyandang disabilitas dengan sendirinya menimbulkan kewajiban bagi negara Indonesia untuk menghormati, melindungi

\footnotetext{
${ }^{1}$ Nurul Qamar, (2018), Hak Asasi Manusia, Jakarta: Sinar Grafika, hlm. 94.

${ }^{2}$ Frichy Ndaumanu, (2020), "Hak Penyandang Disabilitas : Antara Tanggung Jawab Dan Pelaksanaan Oleh Pemerintah Daerah", Jurnal HAM, Volume 11, Nomor 1, April 2020, hlm. 137.

${ }^{3}$ Kartika Gabriela Rompis, (2016), "Perlindungan Hukum Terhadap Penyandang Disabilitas Dalam Perspektif Hukum Hak Asasi Manusia", Jurnal Lex Administratum, Volume 4, Nomor 2, Februari 2016, hlm. 172.

${ }^{4}$ Theresia Degener, (2016), "Disability in a Human Rights Context, Laws", Journal, Volume 5, Nomor 35, Agustus 2016, hlm. 4.

5 H.A.R. Tilaar, (2010), Dimensi-Dimensi Hak Asasi Manusia Dalam Kurikulum Persekolahan Indonesia, Bandung: Alumni, hlm. 21.
} 
dan memenuhinya berdasarkan hukum yang inklusif. Inklusifitas hukum yang dimaksud pada dasarnya telah tercermin dari Pasal 28H Ayat (2) Undang-Undang Dasar Negara Republik Indonesia Tahun 1945. Pasal tersebut diiringi pula dengan Pasal 28I Ayat (2) yang berbunyi "Setiap orang bebas dari perlakuan yang bersifat diskriminatif atas dasar apapun dan berhak mendapatkan perlindungan terhadap perlakuan yang bersifat diskriminatif itu.". 6 Kedua norma dasar yang telah tertera dalam konstitusi itu mengandung makna bahwa setiap manusia mempunyai seperangkat hak asasi yang sama, termasuk penyandang disabilitas yang telah dijamin oleh konstitusi sebagai hak-hak konstitusional. ${ }^{7}$

Seluruh hak konstitusional yang dimiliki oleh penyandang disabilitas menjadi tanggung jawab bagi negara untuk menjaminnya secara paripurna. ${ }^{8}$ Salah satu bentuk aktualisasi dari tanggung jawab tersebut ialah dengan turut sertanya negara Indonesia dalam United Nations Convention on the Rights of Persons with Disabilities (UNCRPD). Tidak hanya berhenti sampai di situ, konvensi internasional yang memuat hak-hak fundamental penyandang disabilitas itu kemudian diadopsi ke dalam hukum nasional melalui mekanisme ratifikasi menjadi Undang-Undang Nomor 19 Tahun 2011 tentang Pengesahan Convention On The Rights Of Persons With Disabilities (Konvensi Mengenai Hak-Hak Penyandang Disabilitas). Lima tahun setelahnya, Dewan Perwakilan Rakyat bersama Presiden berhasil pula mengundangkan Undang-Undang Nomor 8 Tahun 2016 tentang Penyandang Disabilitas sebagai bagian integral dari agenda ramah disabilitas melalui reformasi hukum berdasarkan semangat inklusifitas.

Undang-Undang Nomor 8 Tahun 2016 tentang Penyandang Disabilitas (UndangUndang Penyandang Disabilitas) secara normatif telah mengejawantahkan hak-hak penyandang disabilitas dengan jelas dan menyeluruh. Hal itu dapat terlihat dari Pasal 5 sampai dengan Pasal 26 dalam Bab III yang khusus menguraikan tentang hak-hak penyandang disabilitas. Lebih lanjut, undang-undang tersebut juga membentuk suatu lembaga khusus yang bernama Komisi Nasional Disabilitas (KND) untuk memastikan bahwa komitmen atas penghormatan, perlindungan dan pemenuhan serangkaian hak pada diri penyandang disabilitas benar-benar terlaksana di tengah-tengah masyarakat. Desain

\footnotetext{
${ }^{6}$ Pasal 28I Ayat (2) Undang-Undang Dasar Negara Republik Indonesia Tahun 1945.

${ }^{7}$ Jimly Asshiddiqie, (2013), Komentar Atas Undang-Undang Dasar Negara Republik Indonesia Tahun 1945, Jakarta: Sinar Grafika, hlm. 122-125.

8 Christian Starck, (2000), "State Duties of Protection and Fundamental Right, Potchefstroom Electronic Law", Journal, Volume 3, Nomor 1, Mei 2000, hlm. 29.
} 
kelembagaan yang diusung ialah lembaga independen sebagaimana bunyi dari Pasal 131 Undang-Undang Penyandang Disabilitas.

Harmonisasi norma hukum yang telah dirajut sejak konstitusi pada kenyataannya hanya berhenti sampai taraf undang-undang saja. Pertentangan norma hukum antara undangundang dengan peraturan pelaksana yang berada di bawahnya (Conflict of norms) terlihat sejak terbitnya Peraturan Presiden Nomor 68 Tahun 2020 tentang Komisi Nasional Disabilitas. Salah satu ketentuan yang menjadi fokus permasalahan yaitu terletak pada Pasal 9 Ayat (4) yang mengatur bahwa kedudukan dari sekretariat Komisi Nasional Disabilitas (KND) berada di unit kerja di kementerian yang menyelenggarakan urusan pemerintahan di bidang sosial. ${ }^{9}$ Keberadaan norma tersebut secara eksplisit bertentangan dengan Pasal 131 Undang-Undang Penyandang Disabilitas yang menegaskan bahwa desain KND adalah lembaga independen, di mana prinsip utama dari lembaga tersebut ialah tidak terikatnya seluruh organ yang berada di dalamnya dengan lembaga-lembaga di tiga cabang kekuasaan utama, termasuk kementerian negara sebagai bagian dari kekuasaan eksekutif.

Tidak proporsionalnya desain kelembagaan pada tubuh KND akan berpengaruh juga secara langsung terhadap pelaksanaan fungsi pengawasan yang menjadi jantung dari agenda kemanusiaan berupa penghormatan, perlindungan dan pemenuhan hak-hak penyandang disabilitas. Lemahnya pengawasan dari negara melalui KND yang bersifat independen secara mutatis mutandis berimplikasi pada tidak terselesaikannya berbagai kasus diskriminasi terhadap penyandang disabilitas di bumi pertiwi. Hal itu dapat terbukti secara konkrit dari laporan Indonesia Indicator (I2) yang mencatat hingga agustus 2020, terdapat $27.78 \%$ atau sebanyak 5 dari 18 kasus diskriminasi di tanah air, di antaranya terjadi pada penyandang disabilitas. ${ }^{10}$ Tentu saja realita tersebut telah mencederai hak-hak asasi penyandang disabilitas yang telah dijamin oleh konstitusi sebagai hak konstitusional. ${ }^{11}$

Terjadinya penyimpangan terkait desain kelembagaan dari KND sebagai lembaga independen merupakan permasalahan yang urgen untuk diselesaikan. Hal itu dikarenakan dapat berujung pula pada tidak tercapainya tujuan asli dari lembaga independen itu sendiri, di mana menurut Zainal Arifin Mochtar, salah satu tujuan dari dibentuknya lembaga independen

\footnotetext{
${ }^{9}$ Pasal 9 Ayat (4) Peraturan Presiden Republik Indonesia Nomor 68 Tahun 2020 Tentang Komisi Nasional Disabilitas Lembaran Negara Republik Indonesia Tahun 2020 Nomor 144.

${ }^{10}$ Indonesia Indicator, 17 Agustus 2020, Menelisik Kasus Diskriminasi Minoritas Di Indonesia, Indonesiaindicator.com, http://indonesiaindicator.com/99-publication/release/408-menelisik-kasus-diskriminasiminoritas-di-indonesia.html, diakses tanggal 02 Mei 2021.

${ }^{11}$ Ali Sodiqin, (2021), "Ambigiusitas Perlindungan Hukum Penyandang Disabilitas Dalam PerundangUndangan Di Indonesia", Jurnal Legislasi Indonesia, Volume 18, Nomor 1, Maret 2021, hlm. 41.
} 
itu ialah untuk mewujudkan penghargaan atas kaum minoritas dan merealisasikan prinsip kesetaraan. ${ }^{12}$ Berdasarkan alasan itulah, peneliti akan mengkaji persoalan tersebut lebih jauh dalam penelitian ini guna menemukan akar permasalahan dan solusi yang tepat untuk mengatasinya. Hasil dari penelitian ini akan dituangkan dalam artikel yang berjudul "Penataan Kembali Desain Kelembagaan Komisi Nasional Disabilitas sebagai Lembaga Independen di Indonesia".

\section{RUMUSAN MASALAH}

Permasalahan utama dalam penelitian ini hanya difokuskan pada aspek kelembagaan dari Komisi Nasional Disabilitas, tepatnya problematika terkait ketentuan normatif dari desain kelembagaan Komisi Nasional Disabilitas sebagai lembaga independen di Indonesia. Berpangkal dari permasalahan utama tersebut, maka peneliti akan mengelaborasikannya menjadi beberapa pertanyaan penelitian sebagai berikut:

1) Apa yang dimaksud dengan lembaga independen dalam struktur ketatanegaraan?

2) Apa problematika hukum terkait desain kelembagaan dari Komisi Nasional Disabilitas di Indonesia?

3) Bagaimana desain lembaga independen berdasarkan Pasal 33 Konvensi mengenai Hak-hak Penyandang Disabilitas?

\section{METODE PENELITIAN}

Jenis penelitian pada artikel ini ialah penelitian hukum normatif. Objek utama yang dikaji dalam penelitian hukum normatif ialah seputar norma-norma hukum yang telah dibuat oleh negara dan telah diberlakukan di tengah-tengah masyarakat. ${ }^{13}$ Sementara itu, pendekatan yang digunakan ialah pendekatan perundang-undangan (statutory approach). Maksud dari pendekatan tersebut ialah mengkaji hukum dengan memprioritaskan ketentuan-ketentuan dalam naskah peraturan perundang-undangan yang mengikat secara umum dan dibentuk oleh lembaga negara atau pejabat yang berwenang melalui proses legislasi. ${ }^{14}$

Data yang digunakan dalam penelitian kali ini ialah data sekunder yang diperoleh dari bahan hukum primer dan bahan hukum sekunder. Data yang bersumber dari bahan hukum

\footnotetext{
${ }^{12}$ Zainal Arifin Mochtar, (2019), Lembaga Negara Independen: Dinamika Perkembangan Dan Urgensi Penataannya Kembali Pasca-Amandemen Konstitusi, Depok: Rajagrafindo Persada, hlm. 32.

${ }^{13}$ Sulistyowati Irianto dan Shidarta, (2017), Metode Penelitian Hukum Konstelasi Dan Refleksi, Jakarta: Yayasan Pustaka Obor Indonesia, hlm. 124-128. 137.

${ }^{14}$ Peter Mahmud Marzuki, (2019), Penelitian Hukum Edisi Revisi, Jakarta: Prenadamedia Group, hlm.
} 
primer berupa seperangkat norma hukum baik itu dalam lingkup nasional maupun internasional terkait hak-hak penyandang disabilitas dan lembaga pengawasnya yang bersifat independen. Data tersebut diperoleh dari Undang-Undang Dasar Negara Republik Indonesia Tahun 1945, Undang-Undang Nomor 19 Tahun 2011 tentang Pengesahan Convention On The Rights Of Persons With Disabilities (Konvensi Mengenai Hak-Hak Penyandang Disabilitas), Undang-Undang Nomor 8 Tahun 2016 tentang Penyandang Disabilitas, Peraturan Presiden Nomor 68 Tahun 2020 tentang Komisi Nasional Disabilitas dan United Nations Convention on the Rights of Persons with Disabilities. Tidak hanya itu, data penunjang yang didapatkan dari bahan hukum sekunder yaitu teori-teori dan pendapat ahli tentang hukum kelembagaan negara yang berasal dari buku-buku, artikel-artikel jurnal, makalah-makalah dan literaturliteratur hukum lainnya yang relevan dengan tema penelitian.

Seluruh data dalam penelitian ini didapatkan dengan menerapkan metode pengumpulan data berupa komunikasi tertulis dengan teknik studi dokumen. Teknik tersebut dijalankan oleh peneliti dengan memeriksa dan membaca semua peraturan perundangundangan dan literatur-literatur yang sesuai dengan topik penelitian. Setelah itu, data yang telah diperoleh sebelumnya dianalisa dengan metode deskriptif. Metode tersebut digunakan untuk menggambarkan pokok permasalahan secara detail agar dapat menemukan solusi yang tepat untuk mengatasinya.

\section{PEMBAHASAN}

\section{Lembaga Independen dalam Struktur Ketatanegaraan}

Lembaga Independen dalam perspektif constitutional law memiliki sebutan yang sangat bervariasi. Berbagai istilah yang dimaksud ialah independent regulatory boards, independent regulatory agencies, state auxiliary institutions, self regulatory agency, independent supervisory bodies, intermediate institutions, atau independent regulatory commissions. ${ }^{15}$ Tidak hanya sampai di situ, sebutan-sebutan lain yang kerap kali digunakan pula yaitu lembaga negara sampiran, lembaga negara mandiri, lembaga negara penunjang, lembaga negara pendukung dan lembaga negara yang bersifat sekunder. Bentuk dari lembagalembaga tersebut pun sangat beragam, yaitu ada yang berupa dewan (council), komisi (commission), komite (committee), badan (board), atau otorita (authority). ${ }^{16}$

\footnotetext{
${ }^{15}$ Andi Setiawan, (2015), Pengantar State Auxiliary Agency, Malang: UB Press, hlm. 3.

16 Jimly Asshiddiqie, (2006), Perkembangan, Dan Konsolidasi Lembaga Negara Pasca Reformasi, Jakarta: Sekretaris Jenderal dan Kepaniteraan Mahkamah Konstitusi RI, hlm. 7-8.
} 
Lembaga atau komisi penunjang yang bersifat mandiri dalam struktur ketatanegaraan pada dasarnya berada di luar cabang kekuasaan legislatif, eksekutif maupun yudikatif. Hal itu kerap disebut pula oleh Yves Meny dan Andrew Knapp sebagai cabang kekuasaan keempat (The headless fourth branch' of the government). Mereka berpandangan bahwa "Regulatory and monitoring bodies are a new type of autonomous administration which has been most widely developed in the United States (where it is sometimes referred to as the headless fourth branch' of the government). It take the form of what are generally known as Independent Regulatory Commissions." ${ }^{17}$ Salah satu aspek yang disoroti oleh Yves Meny dan Andrew Knapp ialah fungsi pengawasan (monitoring) yang menjadi entitas utama dari Independent Regulatory Commissions, sehingga secara kelembagaan harus bersifat imparsial dan tidak terbelenggu dalam legislatif, eksekutif maupun yudikatif.

Paradigma pemikiran yang dikembangkan oleh Yves Meny dan Andrew Knapp secara prinsip sejalan pula dengan pendapat Jimly Asshiddiqie. Begawan hukum tata negara asal Indonesia itu berpendapat bahwa lembaga negara tersebut idealnya bersifat independen, sehingga keberadaannya harus terlepas dari tiga cabang utama kekuasaan. ${ }^{18}$ Jimly Asshiddiqie mengungkapkan pula bahwa kehadiran lembaga negara penunjang yang dibentuk secara independen dalam struktur ketatanegaraan tidak terlepas dari perkembangan kehidupan bernegara masyarakat global. Menurutnya, dibentuknya lembaga negara penunjang disebabkan oleh beberapa faktor, yaitu: ${ }^{19}$

1. The need to provide cultural or personal services supposedly free from the risk of political interference, berkembangnya kebutuhan untuk menyediakan pelayanan budaya atau pelayanan secara personal yang diidealkan bebas dari campur tangan politik.

2. The desirability of non-political regulation of markets, adanya keinginan untuk mengatur dinamika pasar yang sama sekali bersifat non politik.

3. The regulation of independent professions such as medicine and the law, keperluan mengatur profesi-profesi yang bersifat independen.

4. The provisions of technical services, kebutuhan untuk mengadakan aturan mengenai pelayanan-pelayanan yang bersifat teknis (technical services).

\footnotetext{
${ }^{17}$ Yves Meny and Andrew Knapp, (1998), Government and Politic in Western Europe: Britain, France, Italy, Germany 3rd edition, Oxford: Oxford University Press, hlm. 22.

18 Jimly Asshiddiqie, (2003), Struktur Ketatanegaraan Indonesia Setelah Perubahan Keempat UUD 1945, Makalah Disampaikan Pada Seminar Pembangunan Hukum Nasional VIII, Denpasar, hlm. 22.

19 Jimly Asshiddiqie, (2008), Hubungan Antar Lembaga Negara Pasca Perubahan UUD 1945, Makalah Disampaikan Pada Seminar Nasional Sekretariat Negara Republik Indonesia, Jakarta, hlm. 8.
} 
5. The creation of informal judicial machinery for settling disputes, terbentuknya berbagai institusi yang berfungsi sebagai alat perlengkapan yang bersifat semi judisial untuk menyelesaikan sengketa di luar peradilan sebagai alternative dispute resolutions (ADR).

Tujuan dari kehadiran lembaga sekunder yang bersifat independen ialah untuk menjawab isu-isu ketatanegaraan yang terjadi secara aktual pada suatu negara. Tingginya kompleksitas tugas-tugas kenegaraan membutuhkan lembaga-lembaga sekunder yang memiliki cukup independensi agar dapat menjalankan tugas, pokok dan fungsinya dengan baik dan benar, tanpa diintervensi oleh lembaga lainnya. ${ }^{20}$ Tidak hanya itu, pembentukan lembaga sekunder yang bersifat independen merupakan upaya penguatan (empowerment) terhadap lembaga-lembaga utama yang telah ada. Hal itu dikarenakan lembaga tersebut sengaja didesain secara spesifik untuk mengurusi tugas tertentu saja, sebagaimana pendapat Michael R. Asimov yang menyatakan bahwa "Agency that created independently by statute to carry out specific tasks in implementing the statute." 21

Lembaga mandiri yang tergolong dalam rumpun auxiliary bodies harus didesain dengan tepat agar independensinya dapat terjamin. Menurut William F. Funk dan Richad H. Seamon, "An agency is said to be independent if the leadership is collective, not just led by a leader; leadership is not controlled by certain political parties; The tenure of agency leaders does not expire simultaneously, but alternately (staggered terms).". ${ }^{22}$ Mereka berpandangan bahwa suatu lembaga dikatakan independen jika kepemimpinannya bersifat kolektif, bukan hanya dipimpin oleh seorang pemimpin; kepemimpinan tidak dikendalikan oleh partai politik tertentu; Masa jabatan pemimpin lembaga tidak berakhir secara bersamaan, tetapi secara bergantian (staggered terms). Pandangan tersebut apabila dielaborasi lebih lanjut, menghasilkan pemahaman bahwa suatu lembaga dapat dikatakan independen jika memenuhi beberapa karakteristik utama sebagai berikut: ${ }^{23}$

1. Dasar legitimasi dari pembentukannya menyatakan secara tegas kemandirian atau independensi.

2. Kedudukan dan struktur kelembagaannya terlepas dari lembaga-lembaga negara di rumpun kekuasaan utama.

\footnotetext{
${ }^{20}$ Lukman Hakim, (2010), Kedudukan Hukum Komisi Negara Di Indonesia, Malang: Program Pasca UB, hlm. 33 .

${ }^{21}$ Michael R Asimov, (2002), Administrative Law, Chicago: The BarBri Group, hlm. 2.

${ }^{22}$ William F Funk and Richard H Seamon, (2001), Administrative Law: Examples and Explanations, New York: Aspen Publisher, hlm. 23.

${ }^{23}$ Marshal J Breger and Gary J Edles, (2015), Independent Agencies in United States: Law, Structure, and Politics, Oxford: Oxford University Press, hlm. 2.
} 
3. Pengangkatan dan pemberhentian ketua dan anggotanya tidak didasarkan pada kehendak Presiden (political appointee), melainkan melalui mekanisme independen yang dibentuk secara khusus.

4. Unsur pimpinan tidak terafiliasi dengan partai politik manapun.

5. Sistem keingatan dari anggota berbasiskan keseimbangan perwakilan atau bersifat nonpartisan.

Pembentukan lembaga penunjang secara independen dalam struktur ketatanegaraan memiliki tujuan lain yaitu untuk mengembalikan kepercayaan publik. Hal itu dikarenakan publik sudah tidak percaya lagi dengan lembaga-lembaga negara yang berada di dalam rumpun kekuasaan utama, sehingga lembaga tersebut didesain dengan karakteristik khusus, yaitu bebas dari pengaruh, kehendak, ataupun kontrol dari cabang kekuasaan manapun, terutama kekuasaan eksekutif. Kepercayaan publik memang sudah semestinya perlu kembali dipulihkan, mengingat keberadaannya menjadi modal dasar untuk meningkatkan partisipasi publik sebagai bagian dari agenda besar reformasi politik. Reformasi politik yang berjalan dengan baik di suatu negara akan menciptakan kehidupan berbangsa dan bernegara yang sangat baik pula ke depannya. ${ }^{24}$

\section{Problematika Hukum terkait Desain Kelembagaan dari Komisi Nasional Disabilitas di}

\section{Indonesia}

Reformasi konstitusi menjadi suatu keharusan bagi Indonesia untuk mewujudkan transformasi politik dan kelembagaan yang dilandaskan pada tuntutan demokratisasi kekuasaan dan perlindungan terhadap hak asasi manusia. Hal itu tentu sangat logis, mengingat peranan konstitusi itu sendiri sangatlah vital, yaitu sebagai the supreme Law of the Land. ${ }^{25}$ Lebih lanjut, K. C. Weare berpandangan bahwa konstitusi secara luas tidak hanya dimaknai sebagai norma hukum yang bersifat mendasar saja, melainkan seluruh norma-norma hukum yang melengkapinya pun dianggap sebagai konstitusi. ${ }^{26}$ Artinya, prinsip-prinsip demokrasi dan perlindungan hak asasi manusia yang menjadi jantung dari reformasi konstitusi tidak hanya tercerminkan pada Undang-Undang Dasar Negara Republik Indonesia Tahun 1945 saja, tetapi harus tercerminkan pula dalam seluruh peraturan perundang-undangan yang berada di bawahnya sebagai satu kesatuan dalam sistem hukum nasional.

\footnotetext{
${ }^{24}$ Syamsuddin Haris, (1999), Reformasi Setengah Hati, Jakarta: Erlangga, hlm. 18.

${ }^{25}$ Frank I Michelman, (2003), "The Constitution, Social Rights, and Liberal Political Justification", I.CON Journal, Volume 1, Nomor 1, Januari 2003, hlm. 13.

${ }^{26}$ K.C. Wheare, (2010), Konstitusi Konstitusi Modern, Bandung: Nusa Media, hlm. 3.
} 
Pengesahan dan pemberlakuan Undang-Undang Nomor 8 Tahun 2016 tentang Penyandang Disabilitas (Undang-Undang Penyandang Disabilitas) merupakan salah satu contoh konkrit dari tercerminnya komitmen terhadap penghormatan, perlindungan dan pemenuhan hak asasi manusia, khususnya hak-hak penyandang disabilitas dalam produk perundang-undangan di tanah air. ${ }^{27}$ Undang-undang tersebut secara substantif telah menjamin seluruh hak-hak penyandang disabilitas dalam berbagai aspek kehidupan. Tidak hanya berhenti sampai di situ, undang-undang yang disahkan pada bulan April 2016 itu juga mengisyaratkan pembentukan komisi khusus bernama Komisi Nasional Disabilitas (selanjutnya disebut dengan KND) sebagaimana amanat Pasal 131, yaitu "Dalam rangka pelaksanaan Penghormatan, Perlindungan, dan Pemenuhan hak Penyandang Disabilitas dibentuk KND sebagai lembaga nonstruktural yang bersifat independen.". ${ }^{28}$ Lebih lanjut, Pasal 134 memberikan penjelasan bahwa "Ketentuan mengenai organisasi dan tata kerja serta keanggotaan KND diatur dengan Peraturan Presiden.". ${ }^{29}$

Pembentukan KND sebagai lembaga nonstruktural yang bersifat independen mulai menemui permasalahan ketika sampai pada tingkat Peraturan Presiden. Penulis menemukan bahwa peraturan turunan yang mengatur lebih lanjut perihal organisasi, tata kerja dan keanggotaan dari lembaga tersebut tidak kunjung diterbitkan. Sejatinya, Pasal 149 mengenai ketentuan peralihan dalam Undang-Undang Penyandang Disabilitas telah menegaskan bahwa "KND sebagaimana dimaksud dalam Pasal 131 harus sudah dibentuk paling lama 3 (tiga) tahun terhitung sejak Undang-Undang ini diundangkan." ${ }^{30}$ Akan tetapi, kenyataannya KND baru terbentuk empat tahun setelahnya, karena Peraturan Presiden Nomor 68 Tahun 2020 tentang Komisi Nasional Disabilitas (Peraturan Presiden Komisi Nasional Disabilitas) baru diterbitkan pada tanggal 8 Juni 2020 dan baru diundangkan tanggal 9 Juni 2020.

Nasib KND yang telah terkatung-katung sedari awal, pada kenyataannya semakin diperburuk paska Peraturan Presiden Komisi Nasional Disabilitas terbit. Desain lembaga independen yang telah terkristalisasikan sedemikian rupa dalam undang-undang, seketika

${ }^{27}$ Anak Agung Istri Ari Atu Dewi, (2018), "Aspek Yuridis Perlindungan Hukum Dan Pemenuhan Hak Penyandang Disabilitas", Jurnal Pandecta, Volume 13, Nomor 1, Juni 2018, hlm. 54.

${ }^{28}$ Pasal 131 Undang-Undang Republik Indonesia Nomor 8 Tahun 2016 Tentang Penyandang Disabilitas Lembaran Negara Republik Indonesia Tahun 2016 Nomor 69 Tambahan Lembaran Negara Republik Indonesia Nomor 5871.

${ }^{29}$ Pasal 134 Undang-Undang Republik Indonesia Nomor 8 Tahun 2016 Tentang Penyandang Disabilitas Lembaran Negara Republik Indonesia Tahun 2016 Nomor 69 Tambahan Lembaran Negara Republik Indonesia Nomor 5871.

${ }^{30}$ Pasal 149 Undang-Undang Republik Indonesia Nomor 8 Tahun 2016 Tentang Penyandang Disabilitas Lembaran Negara Republik Indonesia Tahun 2016 Nomor 69 Tambahan Lembaran Negara Republik Indonesia Nomor 5871. 
direduksi begitu saja dengan diberlakukannya Peraturan Presiden tersebut. Hasil dari penelitian kali ini menunjukkan bahwa terdapat distorsi norma pada Pasal 9 Ayat (4) yang mengatur bahwa Sekretariat KND berkedudukan di unit kerja di kementerian yang menyelenggarakan urusan pemerintahan di bidang sosial. Penempatan organ kesekretariatan KND dalam tubuh kementerian sebagaimana bunyi dari Pasal a quo telah mengkhianati amanat Pasal 131 Undang-Undang Penyandang Disabilitas yang telah menentukan bahwa KND bersifat independen.

Desain kelembagaan KND yang tidak proporsional sebagai lembaga independen membuat fungsi pelaksanaan dan pengawasan yang melekat pada lembaga tersebut tidak berjalan secara optimal. Tidak bekerjanya fungsi pelaksanaan dan pengawasan secara optimal berimplikasi pada tidak terbendungnya praktik-praktik pelanggaran terhadap hak-hak penyandang disabilitas di tengah-tengah masyarakat. ${ }^{31}$ Hal itu dengan jelas terlihat dari maraknya kasus-kasus diskriminasi maupun kekerasan yang dialami oleh penyandang disabilitas yang ada di bumi pertiwi. Salah satu konteks kasus yang sangat memiriskan yaitu tingginya praktik kekerasan pada kaum perempuan yang menyandang disabilitas. Berdasarkan catatan tahunan yang diterbitkan oleh Komisi Nasional Perempuan pada tahun 2021, tindak kekerasan terhadap perempuan disabilitas sepanjang tahun 2020 berjumlah 77 kasus, di mana $42 \%$ di antaranya berupa kekerasan yang bersifat seksual, seperti perkosaan, pencabulan dan eksploitasi seksual. $^{32}$

Realita yang benar-benar terjadi di masyarakat telah menampar wajah Indonesia sebagai negara yang telah berkomitmen untuk menghormati, melindungi dan memenuhi hakhak penyandang disabilitas sebagai bagian dari hak asasi manusia di hadapan masyarakat internasional. Ketaatan Indonesia terhadap prinsip-prinsip baku yang telah termaktub dalam United Nations Convention on the Rights of Persons with Disabilities (UNCRPD) perlu kembali dipertanyakan. Hal itu dikarenakan Indonesia telah menandatangani dan meratifikasinya menjadi Undang-Undang Nomor 19 Tahun 2011 tentang Pengesahan Convention On The Rights Of Persons With Disabilities (Konvensi Mengenai Hak-Hak Penyandang Disabilitas), sehingga telah bersifat mengikat. Oleh karena itu, seluruh irah-irah

\footnotetext{
${ }^{31}$ Hastuti Dkk, (2020), Kendala Mewujudkan Pembangunan Inklusif Penyandang Disabilitas, Jakarta: The SMERU Research Institute, hlm. 30.

${ }^{32}$ Komisi Nasional Perempuan RI, (2021), Perempuan dalam Himpitan Pandemi: Lonjakan Kekerasan Seksual, Kekerasan Siber, Perkawinan Anak, dan Keterbatasan Penanganan di Tengah Pandemi Covid-19, Jakarta, hlm. 57-58, https://komnasperempuan.go.id/uploadedFiles/1466.1614933645.pdf.
} 
yang telah digariskan sebagai tujuan dari konvensi tersebut menjadi kewajiban pula bagi Indonesia untuk merealisasikannya di tanah air. ${ }^{33}$

\section{Desain Lembaga Independen berdasarkan Pasal 33 Konvensi mengenai Hak-hak Penyandang Disabilitas}

United Nations Convention on the Rights of Persons with Disabilities (UNCRPD) merupakan konvensi tertama yang dirancang dengan keterlibatan penuh para penyandang disabilitas. Hal tersebut menjadikan $U N C R P D$ sebagai konvensi terbesar di dunia yang membahas isu terkait hak-hak penyandang disabilitas dengan memperhatikan berbagai aspirasi dari mereka secara langsung. Menurut Amita Dhanda, "It lends an interpreative weight that recognises the contribution of participating organisations, and the aspirations of the broader disability community.". ${ }^{34}$ Artinya, UNCRPD telah memberikan pengakuan yang lebih terhadap organisasi yang berpartisipasi dan berbagai aspirasi dari komunitas disabilitas yang lebih luas, sehingga materi muatan yang dihasilkan pun menjadi komprehensif dan akomodatif.

UNCRPD sebagai guide book of change pada dasarnya berfungsi sebagai pedoman utama bagi negara-negara di penjuru dunia untuk melaksanakan penghormatan, perlindungan dan pemenuhan hak-hak penyandang disabilitas. ${ }^{35}$ Eksistensinya sebagai salah satu konvensi internasional memiliki original intent yaitu untuk memastikan semua penyandang disabilitas dapat menikmati semua hak dasar manusia dan kebebasan yang fundamental. Tujuan kemanusiaan yang sangat mulia itu diejawantahkan lebih lanjut dalam delapan prinsip utama yang menjadi jantung dari UNCRPD. Adapun prinsip-prinsip tersebut ialah: ${ }^{36}$

1. Menghormati martabat yang melekat berupa otonomi individu.

2. Non-diskriminasi.

3. Partisipasi dan inklusi penuh dan efektif dalam masyarakat.

4. Menghormati perbedaan dan penerimaan orang-orang penyandang disabilitas sebagai

bagian dari keragaman manusia dan kemanusiaan.

33 Aprilina Pawestri, (2017), "Hak Penyandang Disabilitas Dalam Perspektif HAM Internasional Dan HAM Nasional", Jurnal Era Hukum, Volume 2, Nomor 1, Juni 2017, hlm. 176-177.

${ }^{34}$ Amita Dhanda, (2007), "Legal Capacity in the Disability Rights Convention: Stranglehold of the Past or Lodestar for the Future?, Syracuse Journal of International Law \& Commerce", Volume 34, Nomor 2, Januari 2007, hlm. 429-430.

${ }^{35}$ RR Putri A Priamsari, (2019), "Hukum Yang Berkeadilan Bagi Penyandang Disabilitas, Jurnal Masalah-Masalah Hukum", Volume 48, Nomor 2, April 2019, hlm. 218.

${ }^{36}$ Fajri Nursyamsi Dkk, (2015), Kerangka Hukum Disabilitas Di Indonesia : Menuju Indonesia Ramah Disabilitas, Jakarta: Pusat Studi Hukum dan Kebijakan Indonesia (PSHK), hlm. 52. 
5. Kesetaraan kesempatan.

6. Aksesibilitas.

7. Kesetaraan antara pria dan wanita serta menghormati kapasitas anak-anak disabilitas yang terus berkembang.

8. Penghormatan terhadap hak anak-anak penyandang disabilitas untuk menjaga identitas mereka.

Seluruh prinsip yang tercerminkan dalam berbagai norma pada UNCRPD tentu saja tidak hanya sekedar hitam di atas putih. Kaidah-kaidah tersebut harus benar-benar diaktualisasikan pada masing-masing negara yang menandatanganinya. Hal itu tampak secara jelas dari adanya Article 33 tentang National implementation and monitoring yang berbunyi "States Parties shall, in accordance with their legal and administrative systems, maintain, strengthen, designate or establish within the State Party, a framework, including one or more independent mechanisms, as appropriate, to promote, protect and monitor implementation of the present Convention. When designating or establishing such a mechanism, States Parties shall take into account the principles relating to the status and functioning of national institutions for protection and promotion of human rights.". ${ }^{37}$ Ketentuan tersebut dengan tegas mengamanatkan negara-negara yang telah mengikatkan diri dengan UNCRPD untuk membentuk suatu kerangka kerja atau mekanisme khusus yang bersifat nonstruktural, imparsial dan independen untuk memantau pelaksanaan penghormatan, perlindungan dan pemenuhan hak-hak penyandang disabilitas.

Indonesia sebagai salah satu negara pihak dalam UNCRPD memutuskan untuk meratifikasi konvensi tersebut tanpa adanya reservasi. Artinya, seluruh norma yang termuat dalam konvensi tersebut menjadi bagian integral yang turut diratifikasi oleh Indonesia, termasuk Article 33 UNCRPD tentang National Implementation and Monitoring. Hal itu terbukti dari adanya Pasal 33 yang tercantum pada bagian salinan terjemahan dalam UndangUndang Nomor 19 Tahun 2011 tentang Pengesahan Convention On The Rights Of Persons With Disabilities (Konvensi Mengenai Hak-Hak Penyandang Disabilitas) atau kerap disebut pula dengan Undang-Undang Pengesahan Konvensi mengenai Hak-hak Penyandang Disabilitas. Pasal tersebut menegaskan bahwa "Negara-Negara Pihak, berdasarkan sistem hukum dan administrasi mereka, memelihara, memperkuat, menunjuk atau membentuk dalam wilayah Negara Pihak, suatu kerangka kerja, termasuk satu atau lebih mekanisme independen, Protocol.

37 Article 33 United Nation Convention on the Rights of Persons with Disabilities and Optional 
sebagaimana diperlukan, untuk memajukan, melindungi dan mengawasi implementasi dari Konvensi ini. Ketika menunjuk atau membentuk suatu mekanisme demikian, Negara-Negara Pihak harus memperhitungkan prinsip-prinsip yang berkaitan dengan status dan berjalannya institusi nasional untuk perlindungan dan pemajuan hak asasi manusia.". 38

Dibuatnya Undang-Undang Pengesahan Konvensi mengenai Hak-hak Penyandang Disabilitas merupakan salah satu prosedur yang harus ditempuh oleh Indonesia untuk mengikatkan diri dengan norma-norma dalam UNCRPD. Konvensi tersebut sejatinya merupakan salah satu bentuk dari perjanjian internasional, sehingga mekanisme pengesahan dalam bentuk undang-undang menjadi wajib hukumnya berdasarkan Pasal 3 juncto Pasal 10 huruf d Undang-Undang Nomor 24 Tahun 2000 tentang Perjanjian Internasional. Serangkaian mekanisme dan persyaratan yang telah ditentukan oleh undang-undang itu pada dasarnya menjadi inti dari proses adopsi spesifik (specific adoption) yang dijalankan agar suatu perjanjian internasional dapat berlaku di tanah air. ${ }^{39}$ Adanya prosedur khusus untuk memberlakukan perjanjian internasional di Indonesia merupakan manifestasi dari kehendak negara, karena menurut Mochtar Kusumaatmadja, negara dalam sudut pandang kaum positifis ialah sumber dari segala hukum, sehingga pranata hukum internasional baru dapat berlaku apabila negara atas kehendak sendiri memutuskan untuk tunduk kepadanya. ${ }^{40}$

Indonesia sebagai negara pihak berdasarkan prinsip hukum internasional telah terikat dengan ketentuan Pasal 33 yang menjadi satu kesatuan dari konvensi mengenai hak-hak penyandang disabilitas. Kerangka substansi dari pasal tersebut yang menekankan bahwa diperlukannya pembentukan kerangka kerja, termasuk satu atau lebih mekanisme independen pada prinsipnya tunduk pada ketentuan yang termuat dalam Paris Principles, di mana salah satunya mengatur mengenai Institusi HAM Nasional atau National Human Rights Institutions (NHRI). Menurut Mental Disability Advocacy Center, karakteristik utama dari NHRI sebagai lembaga yang salah satu fungsinya menjaga pengimplemantasian dari Konvensi mengenai Hak-Hak Penyandang Disabilitas dalam suatu negara ialah bersifat independen, yaitu harus imparsial, bebas dari intervensi yang tidak seharusnya, dan dapat menjaga kredibilitasnya di

38 Pasal 33 Undang-Undang Republik Indonesia Nomor 19 Tahun 2011 Tentang Pengesahan Convention On The Rights Of Persons With Disabilities (Konvensi Mengenai Hak-Hak Penyandang Disabilitas) Lembaran Negara Republik Indonesia Tahun 2011 Nomor 107 Tambahan Lembaran Negara Republik Indonesia Nomor 5251.

${ }^{39}$ J.G. Starke, (1988), Pengantar Hukum Internasional 1, Jakarta: Aksara Persada Indinesia, hlm. 68.

40 Mochtar Kusumaatmadja dan Etty R Agoes, (2010), Pengantar Hukum Internasional, Bandung: Alumni, hlm. 49. 
tengah-tengah masyarakat. ${ }^{41}$ Dengan demikian, keberadaannya tidak akan terpengaruh dan berdiri sendiri atau tidak berpihak.

Konsekuensi logis yang harus diterima oleh Indonesia yaitu Komisi Nasional Disabilitas yang telah dibentuk oleh Presiden berdasarkan Peraturan Presiden Komisi Nasional Disabilitas harus sejalan dengan desain lembaga independen sebagaimana yang dimaksud dalam konvensi mengenai hak-hak penyandang disabilitas. Desain lembaga independen yang dimaksud setidak-tidaknya memenuhi beberapa kriteria utama baik dalam hal kedudukan, pemilihan komisioner dan unsur keanggotaan dari komisi tersebut. Kedudukan KND beserta seluruh struktur yang berada di dalamnya baik itu posisi pimpinan, kesekretariatan dan seluruh divisi harus benar-benar imparsial dalam arti berdiri sendiri dan terlepas secara kelembagaan dari lembaga-lembaga negara di rumpun legislatif, eksekutif dan yudikatif. Tidak hanya itu, unsur pimpinan dan keanggotaan dari komisi tersebut juga harus dipilih dan diangkat dalam jumlah yang proporsional dari kelompok penyandang disabilitas itu sendiri dan unsur civil society lainnya berdasarkan mekanisme seleksi yang dijalankan secara independen. Semua itu semata-mata ditujukan agar komisi yang dibentuk dapat menjalankan tugas, pokok dan fungsinya secara optimal, sehingga penghormatan, perlindungan dan pemenuhan hak-hak penyandang disabilitas dapat terwujud secara hakiki di tengah-tengah masyarakat.

\section{PENUTUP}

\section{Kesimpulan}

Lembaga independen dengan berbagai macam sebutannya pada hakikatnya merupakan bagian dari dinamika struktur ketatanegaraan yang terus berkembang seiring dengan meningkatnya paham demokrasi. Kehadirannya ditujukan untuk mengimbangi pilar-pilar kekuasaan di rumpun legislatif, eksekutif dan yudikatif agar tidak cenderung melakukan penyalahgunaan dan melanggar hak-hak asasi manusia. Oleh karena tujuan itulah, lembaga tersebut sengaja didudukkan di luar ketiga rumpun kekuasaan utama pada suatu negara. Tidak hanya itu, unsur pimpinan dan keanggotaan dari lembaga independen juga didesain mayoritas dari masyarakat sipil, kaum intelektual dan profesional agar dapat fokus mengurusi persoalan-

${ }^{41}$ Mental Disability Advocacy Center, (2011), Building the Architecture for Change: Guidelines on Article 33 of the UN Convention on the Rights of Persons with Disabilities, Budapest: Mental Disability Advocacy Center, hlm. 39-40. 
persoalan negara di bidang tertentu yang bersifat spesifik. Desain kelembagaan yang demikian itu merupakan manifestasi dari prinsip-prinsip demokrasi, karena melibatkan partisipasi publik di dalamnya sebagai kunci utama dalam menyelesaikan berbagai persoalan kenegaraan yang semakin kompleks.

Problematika hukum mulai muncul ketika desain lembaga independen tidak tercerminkan pada Komisi Nasional Disabilitas yang dibentuk berdasarkan Peraturan Presiden Nomor 68 Tahun 2020 tentang Komisi Nasional Disabilitas. Hal itu tampak secara nyata pada materi muatan dari Pasal 9 Ayat (4) Peraturan Presiden tersebut yang meletakkan kesekretariatan dari Komisi Nasional Disabilitas di dalam internal Kementerian Negara di bidang sosial yang menjadi representasi dari rumpun eksekutif. Tentu saja kenyataan itu bertentangan dengan desain lembaga independen sebagaimana yang tertera pada Pasal 131 Undang-Undang Nomor 8 Tahun 2016 tentang Penyandang Disabilitas sebagai tindak lanjut dari amanat Article 33 tentang National implementation and monitoring dalam United Nations Convention on the Rights of Persons with Disabilities yang telah disahkan menjadi Undang-Undang Nomor 19 Tahun 2011 tentang Pengesahan Convention On The Rights Of Persons With Disabilities (Konvensi Mengenai Hak-Hak Penyandang Disabilitas). Komisi Nasional Disabilitas yang terganggu independensinya secara desain kelembagaan membuat implementasi dari fungsi pelaksanaan dan pengawasan menjadi tidak optimal, sehingga berimplikasi pada maraknya kasus-kasus diskriminasi dan kekerasan yang diderita oleh penyandang disabilitas di tengah-tengah masyarakat. Oleh karena itu, diperlukannya upaya penataan kembali terhadap desain kelembagaan dari Komisi Nasional Disabilitas agar agenda kemanusiaan berupa penghormatan, perlindungan dan pemenuhan hak-hak penyandang disabilitas dapat terwujud di tanah air.

\section{Saran}

Berdasarkan hasil penelitian yang telah dijabarkan dalam artikel ini, terdapat beberapa saran yang ditujukan kepada Presiden. Hal itu dikarenakan Presiden merupakan otoritas tertinggi yang merancang dan mengesahkan Peraturan Presiden Nomor 68 Tahun 2020 sebagai dasar legitimasi dari terbentuknya Komisi Nasional Disabilitas. Adapun saran atau rekomendasi tersebut ialah merevisi ketentuan yang termaktub pada Pasal 9 Ayat (4) Peraturan Presiden Nomor 68 Tahun 2020 tentang Komisi Nasional Disabilitas yang mengatur kedudukan organ kesekretariatan dari komisi itu sendiri. Selanjutnya, mengesahkan 
dan mengundangkan kembali Peraturan Presiden hasil revisi tersebut sebagai landasan hukum bagi Komisi Nasional Disabilitas yang independen, imparsial dan nonstruktural. 


\section{Buku}

\section{DAFTAR PUSTAKA}

Asimov, Michael R. (2002). Administrative Law. Chicago: The BarBri Group.

Asshiddiqie, Jimly. (2013). Komentar Atas Undang-Undang Dasar Negara Republik Indonesia Tahun 1945. Jakarta: Sinar Grafika.

Asshiddiqie, Jimly. (2006). Perkembangan, Dan Konsolidasi Lembaga Negara Pasca

Reformasi. Jakarta: Sekretaris Jenderal dan Kepaniteraan Mahkamah Konstitusi RI.

Breger, Marshal J and Gary J Edles. (2015). Independent Agencies in United States: Law,

Structure, and Politics. Oxford: Oxford University Press.

Funk, William F and Richard H Seamon. (2001). Administrative Law: Examples and

Explanations. New York: Aspen Publisher.

Hakim, Lukman. (2010). Kedudukan Hukum Komisi Negara Di Indonesia. Malang: Program

Pasca UB.

Haris, Syamsuddin. (1999). Reformasi Setengah Hati. Jakarta: Erlangga.

Hastuti Dkk. (2020). Kendala Mewujudkan Pembangunan Inklusif Penyandang Disabilitas. Jakarta: The SMERU Research Institute.

Irianto, Sulistyowati dan Shidarta. (2017). Metode Penelitian Hukum Konstelasi Dan Refleksi. Jakarta: Yayasan Pustaka Obor Indonesia.

Kusumaatmadja, Mochtar dan Etty R Agoes. (2010). Pengantar Hukum Internasional. Bandung: Alumni.

Marzuki, Peter Mahmud. (2019). Penelitian Hukum Edisi Revisi. Jakarta: Prenadamedia Group.

Mental Disability Advocacy Center. (2011). Building the Architecture for Change: Guidelines on Article 33 of the UN Convention on the Rights of Persons with Disabilities. Budapest: Mental Disability Advocacy Center.

Meny, Yves and Andrew Knapp. (1998). Government and Politic in Western Europe: Britain, France, Italy, Germany 3rd edition. Oxford: Oxford University Press.

Mochtar, Zainal Arifin. (2019). Lembaga Negara Independen: Dinamika Perkembangan Dan Urgensi Penataannya Kembali Pasca-Amandemen Konstitusi. Depok: Rajagrafindo Persada.

Nursyamsi, Fajri Dkk. (2015). Kerangka Hukum Disabilitas Di Indonesia : Menuju Indonesia Ramah Disabilitas. Jakarta: Pusat Studi Hukum dan Kebijakan Indonesia (PSHK). 
Qamar, Nurul. (2018). Hak Asasi Manusia. Jakarta: Sinar Grafika.

Setiawan, Andi. (2015). Pengantar State Auxiliary Agency. Malang: UB Press.

Starke, J.G. (1988). Pengantar Hukum Internasional 1. Jakarta: Aksara Persada Indinesia.

Tilaar, H.A.R. (2010). Dimensi-Dimensi Hak Asasi Manusia Dalam Kurikulum Persekolahan Indonesia. Bandung: Alumni.

Wheare, K.C. (2010). Konstitusi Konstitusi Modern. Bandung: Nusa Media.

\section{Peraturan Perundang-Undangan}

Undang-Undang Dasar Negara Republik Indonesia Tahun 1945

United Nation Convention on the Rights of Persons with Disabilities and Optional Protocol

Undang-Undang Republik Indonesia Nomor 19 Tahun 2011 Tentang Pengesahan Convention On The Rights Of Persons With Disabilities (Konvensi Mengenai Hak-Hak Penyandang Disabilitas) Lembaran Negara Republik Indonesia Tahun 2011 Nomor 107 Tambahan Lembaran Negara Republik Indonesia Nomor 5251

Undang-Undang Republik Indonesia Nomor 8 Tahun 2016 Tentang Penyandang Disabilitas Lembaran Negara Republik Indonesia Tahun 2016 Nomor 69 Tambahan Lembaran Negara Republik Indonesia Nomor 5871

Peraturan Presiden Republik Indonesia Nomor 68 Tahun 2020 Tentang Komisi Nasional Disabilitas Lembaran Negara Republik Indonesia Tahun 2020 Nomor 144

\section{Jurnal}

Atu Dewi, Anak Agung Istri Ari. (2018). "Aspek Yuridis Perlindungan Hukum Dan Pemenuhan Hak Penyandang Disabilitas”. Jurnal Pandecta. Volume 13. Nomor 1. Juni 2018.

Degener, Theresia. (2016). "Disability in a Human Rights Context”. Laws Journal. Volume 5. Nomor 35. Agustus 2016.

Dhanda, Amita. (2007). "Legal Capacity in the Disability Rights Convention: Stranglehold of the Past or Lodestar for the Future?". Syracuse Journal of International Law \& Commerce. Volume 34. Nomor 2. Januari 2007.

Michelman, Frank I. (2003). "The Constitution, Social Rights, and Liberal Political Justification”. I.CON Journal. Volume 1. Nomor 1. Januari 2003.

Ndaumanu, Frichy. (2020). "Hak Penyandang Disabilitas: Antara Tanggung Jawab Dan Pelaksanaan Oleh Pemerintah Daerah”. Jurnal HAM. Volume 11. Nomor 1. April 2020. 
Pawestri, Aprilina. (2017). "Hak Penyandang Disabilitas Dalam Perspektif HAM Internasional dan HAM Nasional". Jurnal Era Hukum". Volume 2. Nomor 1. Juni 2017.

Priamsari, RR Putri A. (2019). "Hukum Yang Berkeadilan Bagi Penyandang Disabilitas”. Jurnal Masalah-Masalah Hukum. Volume 48. Nomor 2. April 2019.

Rompis, Kartika Gabriela. (2016). "Perlindungan Hukum Terhadap Penyandang Disabilitas Dalam Perspektif Hukum Hak Asasi Manusia”. Jurnal Lex Administratum. Volume 4. Nomor 2. Februari 2016.

Sodiqin, Ali. (2021). "Ambigiusitas Perlindungan Hukum Penyandang Disabilitas Dalam Perundang-Undangan Di Indonesia”. Jurnal Legislasi Indonesia. Volume 18. Nomor 1. Maret 2021.

Starck, Christian. (2000). "State Duties of Protection and Fundamental Right". Potchefstroom Electronic Law Journal. Volume 3. Nomor 1. Mei 2000.

\section{Internet}

Indonesia Indicator. 17 Agustus 2020. Menelisik Kasus Diskriminasi Minoritas Di Indonesia. Indonesiaindicator.com. $\quad$ http://indonesiaindicator.com/99-publication/release/408menelisik-kasus-diskriminasi-minoritas-di-indonesia.html.

\section{Lain-Lain}

Asshiddiqie, Jimly. (2008). Hubungan Antar Lembaga Negara Pasca Perubahan UUD 1945. Makalah Disampaikan Pada Seminar Nasional Sekretariat Negara Republik Indonesia. Jakarta.

Asshiddiqie, Jimly. (2003). Struktur Ketatanegaraan Indonesia Setelah Perubahan Keempat UUD 1945. Makalah Disampaikan Pada Seminar Pembangunan Hukum Nasional VIII. Denpasar.

Komisi Nasional Perempuan RI. (2021). Perempuan dalam Himpitan Pandemi: Lonjakan Kekerasan Seksual, Kekerasan Siber, Perkawinan Anak, dan Keterbatasan Penanganan di Tengah Pandemi Covid-19. Jakarta. https://komnasperempuan.go.id/uploadedFiles/1466.1614933645.pdf. 